Vol 1 Issue 2 (2019)

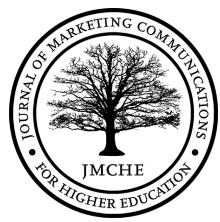

\title{
Formulating a Case for the "Brand Encapsulation Model" and its viability within the Higher Education Sector
}

\author{
Patrick R. Goncalves M.S. Boston College
}

\section{Introduction}

This study will make a case for the use of a new brand valuation model called the "brand encapsulation model"; this model will build upon research conducted by David Aaker and will be proposed for the higher education sector. A survey will include a presentation of a branded item and a non-branded item to prospective consumers of varying demographics. Prospective consumers will be asked which product they would likely consume. In order to prove the validity of the brand encapsulation model, the survey will require that all of the respondents choose the branded item.

\section{What is "Brand"?}

David Aaker is considered by many as the "Father of Modern Branding." Aaker has developed several branding constructs such as the Aaker brand vision model and Aaker brand equity model; additionally, Aaker has written 16 books and published hundreds of articles, all on the topic of branding. ${ }^{1}$ Aaker succinctly describes a brand as:

A set of assets (or liabilities) linked to a brand's name and symbol that adds to (or subtracts from) the value provided by a product or service... ${ }^{2}$

Many other experts on branding have provided a similar definition for the concept of "brand":

...name, term, sign symbol (or a combination of these) that identifies the maker or seller of the product. - Philip Kotler ${ }^{3}$

A brand is the set of expectations, memories, stories and relationships that, taken together, account for a consumer's decision to choose one product or service over another. If the consumer (whether it's a business, a buyer, a voter or a donor) doesn't pay a premium, make a selection or spread the word, then no brand value exists for that consumer. - Seth Godin ${ }^{4}$

\footnotetext{
${ }^{1}$ David Aaker, “David Aaker,” https:/www.prophet.com/author/david-aaker/, (March 5, 2019).

${ }^{2}$ David Aaker, Building Strong Brands (The Free Press, 1996), 7.

${ }^{3}$ Philip Kotler, and Gary Armstrong Principles of Marketing (Upper Saddle River: Pearson, 2018).

${ }^{4}$ Seth Godin, "Define: Brand," https://seths.blog/2009/12/define-brand/, (March 5, 2019).
}

(C) 2019 Patrick R. Goncalves M.S.

This open access article is licensed under a Creative Commons Attribution: Non-Commercial license. DOI: JMCHE/vli201 
Vol 1 Issue 2 (2019)

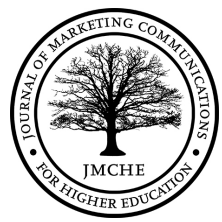

\section{Brand Valuation Models}

In September of 2010, a specification known as the ISO 10668 Standard was developed by the International Organization for Standardization (ISO) in order to provide businesses with a framework to measure the value of their brand by providing formal standards that focus on financial, legal and behavioral aspects. ${ }^{5}$

ISO 10668 has established three brand evaluation methods: the cost approach, the market approach, and the income approach. It is important to note that each valuation method can produce varying valuations. Method selection is contingent upon the appropriability of any given method in connection with relevant, available data. In August of 2011, Brand Finance conducted an overview report of ISO 10668. The report went on to describe the three approaches in specific detail. ${ }^{6}$ Please refer to Index A, B, and C for complete definitions on brand valuation models, analysis points, and applications.

According to ISO 10668, the market approach is ultimately a sales comparison approach conducted between similar brands to arrive at a relative brand valuation. One discrepancy related to the market approach is that relative based valuations do not address a particular brand's valuation to begin with, which presents challenges in determining valuations as though brands may be similar, no two brands are exactly alike. Therefore, the market approach is a logical approach for presenting comparable brands but not a strong approach for establishing a singular brand value. The income approach utilizes the present value of a brand as it relates to the brand's future earning potential. Though ISO 10668 presents various income-based methods for determining brand value by the income approach, premium value methods for example, do not fully represent the experience between brand and consumer choice. A store brand, by definition, is a fully functioning brand that can ascertain self-expressive benefits within the consumer's experience. The argument is that self-expressive benefits are entirely subjective and therefore vary from consumer to consumer. As a result, basing a premium valuation method as a basis for brand value falls short of addressing brand value that is created by brands that do not enlist a price premium.

\footnotetext{
5 "How strong is your company's brand? An ISO can help tell you," International Organization for Standardization (ISO), https://www.iso.org/news/2010/10/Ref1364.html, (March 20, 2019).

6 "Overview of ISO 10668: Brand Valuation," Australian Marketing Institute and Brand Finance, https://brandfinance.com/images/upload/iso_10668_overview.pdf, (March 20 2019).
}

(C) 2019 Patrick R. Goncalves M.S.

This open access article is licensed under a Creative Commons Attribution: Non-Commercial license. DOI: JMCHE/vli201 
The cost-based approach arrives at a brand valuation by determining the cost associated with building or reproducing the brand. The cost approach alone is a one-dimension approach to determining brand valuation, which in turn neglects to embrace other dimensions that contribute to the overall brand value. The three brand valuation methods (market, income, and cost) do not account for value that is tied into brand equity i.e. brand visibility, customer loyalty etc. Experiential factors associated with brand-building are becoming increasingly more prevalent when determining brand value. Marketing author Sergio Zyman concludes that:

A brand is essentially a container for a customer's complete experience with the product or company. ${ }^{7}$

\section{Brand Valuation vs Brand Equity (defined by David Aaker)}

David Aaker defines brand value as:

Brand value...is the financial worth of the brand. To determine brand value, businesses need to estimate how much the brand is worth in the market - in other words, how much would someone purchasing the brand pay? ${ }^{8}$

Aaker makes note that positive brand value does not necessarily equate to positive brand equity. Brand equity on the other hand is defined by Aaker as:

... a set of assets or liabilities in the form of brand visibility, brand associations and customer loyalty that add or subtract from value of a current or potential product or service driven by the brand. It is a key construct in the management of not only marketing, but also business strategy. ${ }^{9}$

Aaker goes on to point out that while measuring brand value is a straight forward approach, measuring brand equity requires more considerations which pertain to assets and/or liabilities in the form of brand visibility, brand associations and customer loyalty. It is fair to conclude based on Aaker's definitions that brand equity is strongly connected to customer perception, which in turn may be translated into a monetary value (brand value). Therefore, an increase in brand equity can illicit an increase in brand value, thereby confirming the value correlation between brand equity and brand value. Since utilizing customer perception as an asset/liability is abstract in nature, brand valuation measurements are subject to a varying degree of deviation, in addition to the varying valuations determined by the use of the ISO 10668 approved brand valuation

\footnotetext{
${ }^{7}$ Mark Bonchek and Cara France, "Build Your Brand as a Relationship," https://hbr.org/2016/05/build-your-brandas-a-relationship, (March 20, 2019).

${ }^{8}$ David Aaker, "Brand Equity vs Brand Value: What's the Difference," https://www.prophet.com/2016/09/brandequity-vs-brand-value/, (March 20, 2019).

${ }^{9}$ David Aaker, "Brand Equity vs Brand Value: What's the Difference," https://www.prophet.com/2016/09/brandequity-vs-brand-value/, (March 20, 2019).
}

(C) 2019 Patrick R. Goncalves M.S.

This open access article is licensed under a Creative Commons Attribution: Non-Commercial license.

DOI: JMCHE/vli201 
models. To summarize, despite the efforts of establishing a brand valuation standard (ISO 10668) the process of determining brand value is not an exact science.

\section{Skepticism on Current Brand Valuation Models}

In 2015, marketing professor (Melborne Business School), Mark Ritson called into question the validity of brand valuation models. Ritson goes on to write:

...published estimates of brand equity were wildly different from each other. For example, there was more than \$100,000,000,000 of difference between what Interbrand said Apple was worth and Millward Brown's estimate... I would argue that if you can't agree on the value of something within a \$100bn of your peers and if your estimates are shown to be $250 \%$ inflated over reality, it's time to declare the value of valuation to be nil. ${ }^{10}$

The $250 \%$ inflation estimate that Ritson was referring to was attributed by a firm known as Markables. As a firm, Markables specializes in auditing trademark and brand valuations. In a report released in 2015, Markables illustrated the large deviations in brand valuations between the top 3 brand valuation firms, Brand Finance, Interbrand, and Millward Brown (BrandZ). The report compared 82 pairs of valuations; firm valuations (Brand Finance, etc.) to the actual price paid for brands (what Markables refers to as "fair values"). The overall deviation across all 82 comparisons was approximately $250 \% .^{11}$

Subsequently, at The Festival of Marketing in October of 2015, Ritson joined representatives from all three brand valuation firms to argue the validity of brand valuation. The representatives were Michael Rocha, global director of brand valuation at Interbrand, Doreen Wand, global head of BrandZ at Millward Brown and David Haigh, founder and CEO of Brand Finance. All three representatives were poised to refute Riston's argument, leading to an audience poll that concluded in a 50/50 vote; $50 \%$ voting for the idea that brand valuation is not valid and $50 \%$ voting on brand valuation being a valid practice. ${ }^{12}$

With an average deviation of $250 \%$ (Markables report) coupled with an inconclusive value judgement made by seasoned marketing professionals, it is fair to say that the practice of brand valuation has and will continue to come into question due to inconsistent valuations which reinforce the idea that even though brand valuation is a "straight forward" process, the

\footnotetext{
${ }^{10}$ Mark Ritson, "What is the point of brand valuations if those doing the valuing are so off target," https:/www.marketingweek.com/2015/04/22/what-is-the-point-of-brand-valuations-if-those-doing-the-valuing-areso-off-target/, (March 20, 2019).

11 "How Accurate are the Brand Value Rankings," Markables, https://www.markables.net/files/How-Accurate-arethe-Brand-Value-Rankings.pdf, (March 20, 2019).

12 Mark Ritson, "Brand Valuation Brilliant of Bullshit," https://www.marketingweek.com/2015/12/08/brandvaluation-brilliant-or-bullshit/, (March 23, 2019).
}

(C) 2019 Patrick R. Goncalves M.S.

This open access article is licensed under a Creative Commons Attribution: Non-Commercial license. DOI: JMCHE/vli201 


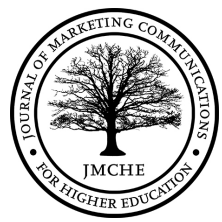

intangibility factor of assets related to brand equity i.e. brand awareness, brand associations, and customer loyalty can potentially play a role in creating discrepancies between valuations. An approach to create a more consistent valuation basis would be to adjust or expand the role and concept of brand.

\section{The Brand Encapsulation Model}

David Aaker goes on to write:

Sometime in the late 1980s, an explosive idea emerged that brands are assets, have equity and drive overall business strategy and performance. That idea altered perceptions of what marketing does, who does it, and to what end is its purpose. ${ }^{13}$

Investopedia.com defines an asset as:

An asset is anything of value or a resource of value that can be converted into cash. ${ }^{14}$

The conflicting idea between "brand as asset" and "asset" as any form of value that can be converted into cash is that under the "brand as asset" perspective, brands are not typically bought or sold (converted to cash). For example, Google reported the greatest brand value under BrandZ's “Top 100 Most Valuable Global Brands 2018” at approximately \$302 billion. ${ }^{15}$ If Google as a company decided to sell their brand to a fruit packaging business, then it is fair to assume that both Alphabet Inc. (Google parent company) and the new Google fruit packaging business would both economically cannibalize one another as a result of sheer consumer confusion. This notion supports the idea that even though there is perceived value associated with brands, it does not necessarily qualify the brands as functional assets. Therefore, brands are non-functioning assets that offer abstract value that adhere to an all-encompassing value perspective. Thereby confirming that brand value is encapsulated with business value, a brand and its respective business (product and/or service) are one. Re-affirming Zyman's thought of brands serving as containers for a customer's complete experience.

\footnotetext{
${ }^{13}$ David Aaker, "Brand as Assets: The Idea that Transformed Marketing," https://www.prophet.com/2014/07/200brands-as-assets-the-idea-that-transformed-marketing/, (March 23, 2019).

${ }^{14}$ Jean Folger, "What is an asset," https://www.investopedia.com/ask/answers/12/what-is-an-asset.asp, (March 23, 2019).

15 "Brand Z Top 100 Most Valuable Global Brands," Millward Brown, https://brandz.com/admin/uploads/files/BZ Global 2018 DL.pdf, (March 23, 2019).
}

(C) 2019 Patrick R. Goncalves M.S.

This open access article is licensed under a Creative Commons Attribution: Non-Commercial license. DOI: JMCHE/vli201 


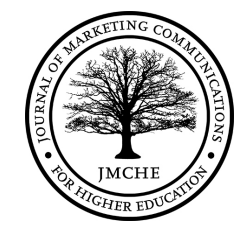

Furthermore, referring to the previous example definitions of brand there is a common thread among all the definitions that echoes the idea of experiential. As humans, experience is provided to us through our senses, in essence our senses submit information that we interpret, therefore brands are simply informational constructs and the idea of brand can be further defined as:

Any and all informational constructs that are strategically placed to provide a basis for consumeristic trust and loyalty to occur or, unintentionally not to occur, within the facilitation of any and all types of monetary transactions.

By this definition, "any and all" experience with a product is by default a brand experience. If any and all experiences are ultimately brand experiences then the brand value must be equal to, or encapsulate the total value of the business it is connected to. Accepting a brand concept of this nature eliminates all deviations tied to brand valuations, and not only reinforces the accepted idea that marketing gets a seat at the table but rather marketing/branding is one with the respective business. The brand encapsulation model states:

For Profit Brands: Brand at present time $(\mathrm{PT})=$ Business Market Cap at PT For Non-Profit (specifically higher ed institutions): Brand at PT = Endowment at PT

In order to build a case for the brand encapsulation model, a survey will be administered measuring the experiential influence of a branded product. Since the brand encapsulation model is an all-encompassing model in the sense that valuations are equal to market cap (for profit) and endowment (non-profit), then survey results would need to illustrate a $100 \%$ bias toward the branded choice.

\section{Poland Spring Survey}

In order to comparatively understand the influential qualities of the "brand experience" a survey of buyer's choice was selected. The survey includes a branded product offering brand qualities that are communicated through symbology, packaging and vision statement. The branded product will be juxtaposed with a non-branded product, meanwhile both products will offer the same exact benefit.

\section{Why Water?}

Selecting the product for the survey was based on the notion of accessibility, for instance, it is common knowledge that water is the most abundant natural resource on the planet, in addition, a consumer can always choose to alternatively gain access to free water (all things being equal, not taking into consideration the socioeconomic discrepancies pertaining to access to clean water in some parts of the world). Water as a product contains attributes that are virtually impartial, void of taste and visual information. The lack of visual information associated with water makes water anonymous, which allows for a stronger basis for measuring brand loyalty.

(C) 2019 Patrick R. Goncalves M.S.

This open access article is licensed under a Creative Commons Attribution: Non-Commercial license. DOI: JMCHE/v1i201 
The overall product experience associated with consuming water is purely an experience based on necessity, consuming water does not require a compelling story or brand vision, quite simply, if we do not consume water we die; that in essence is the underlying story and central product offering, continued life. With consideration to the qualities pertaining to necessity and its accessibility, it is fair to deduce that the bottled water market is entirely a business built on branded strategies. Water sourced from exclusive parts of the world may include offerings such as a different profile of minerals, which in turn play a part in gaining market differentiation. Ultimately, the product offering whether communicated through the brand or not will always be one adhering to sustenance, and there will always be a free alternative, offering equal benefits. Therefore, water was chosen as the most impartial product for evaluating brand influence during the point of sale.

\section{Why Poland Spring?}

It is important to differentiate between other forms of waters such as carbonated and flavored water in order to isolate preference based on the brand experience, because flavored water and carbonated water do not occur in nature. There are literally thousands of various bottled water brands in the world. In 2017, the bottled water market (still water) was estimated to be around \$156 billion:

Global Bottled Water Market Value (By Product Type, 2017 (US\$ Bn) ${ }^{16}$

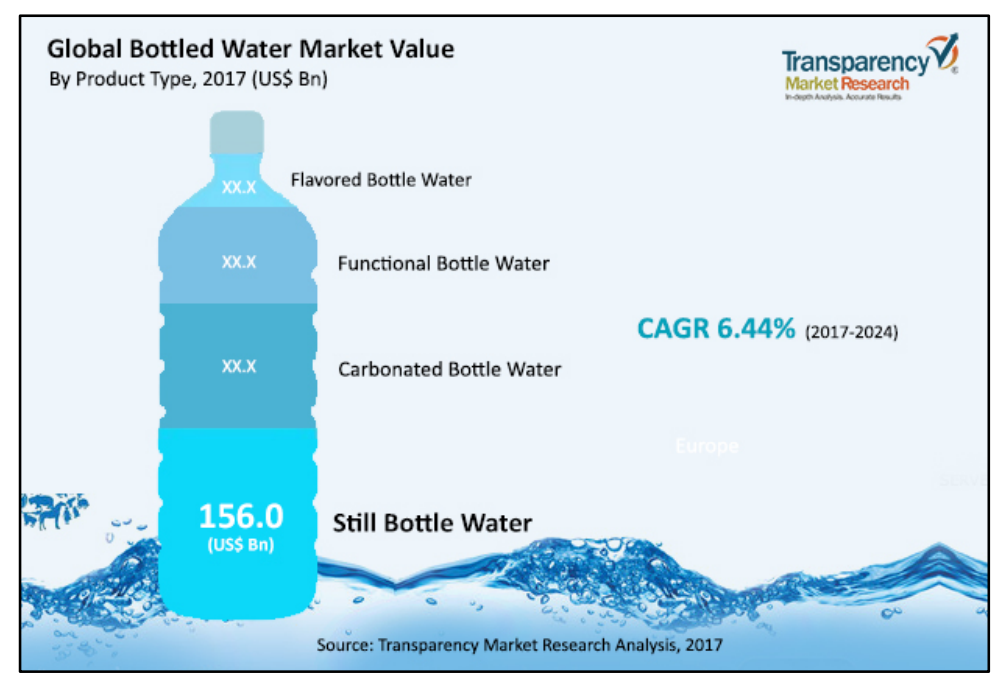

Figure 1. Global Bottled Water Market Value (Transparency Market Research Analysis, 2017)

16 “Key Facts About the Global Bottled Water Market," Transparency Market Research,
https://www.transparencymarketresearch.com/pressrelease/bottled-water-market.htm, (March 23, 2019).

(C) 2019 Patrick R. Goncalves M.S.

This open access article is licensed under a Creative Commons Attribution: Non-Commercial license. DOI: JMCHE/v1i201 
Selection of the bottled water brand was based on three factors: natural sourcing, gender neutrality, and brand awareness (more specifically brand recall). Poland Spring was chosen due to the company's use of natural sources, springs in Maine, specifically sourcing " $100 \%$ natural spring water" from Poland Spring and Garden Spring in Poland, Maine, Clear Spring in Hollis, Evergreen Spring in Fryeburg, Spruce Spring in Pierce Pond Township, White Cedar Spring in Dallas Plantation, and Bradbury Spring in Kingfield. ${ }^{17}$

Considering the survey was conducted in the New England area (Boston College), Poland Spring is widely accessible, and it abides by a strong brand awareness factor. Poland Spring's symbology is representative of nature. Poland Spring bottles are packaged with picturesque wrapping depicting pine trees surrounding a central, flowing spring. The predominant colors used in the packaging are blue and green, likewise, the Poland Spring website (www.polandspring.com) is filled with banner images of outdoor pines and springs all of which echo the brand's colors, green and blue.

Poland Spring as a brand does not portray any visual messaging elements (color, symbols etc.) that target a single gender, as a result, it is fair to conclude that the Poland Spring brand is gender neutral. Lastly, the Poland Spring vision statement echoes the brand's visual elements:

Poland Spring: 100\% natural spring water and proud of it. A lot has changed since we got our start in 1854, but at least one thing remains the same: Poland Spring Brand $100 \%$ Natural Spring Water is still sourced from our carefully selected springs in Maine. ${ }^{18}$

\section{"Non-Brand" is Brand}

As previously stated, parameters of brand pertaining to this study constitute "any and all informational constructs that are strategically placed to provide a basis for consumeristic trust and loyalty to occur." As a result, store brands, such as CVS branded products, are still considered brands. The notion of "non-brand" has carved out a segment in the market place. For example, the brand Brandless has created an illusory brand identity that is predicated on the exclusion of the idea of brand. The Brandless vision statement reads:

Brandless was brought to life on July 11, 2017 with the intention of making better stuff accessible and affordable for more people. Our mission is deeply rooted in quality, transparency, and community-driven values. Better stuff, fewer dollars. It's that simple. ${ }^{19}$

\footnotetext{
17 “Our Springs," Poland Spring, https://www.polandspring.com/our-springs, (March 23, 2019).

18 “Homepage,” Poland Spring, https://www.polandspring.com, (March 23,2019).

19 “About page,” Brandless, https://brandless.com/about, (April 5, 2019).
}

(C) 2019 Patrick R. Goncalves M.S.

This open access article is licensed under a Creative Commons Attribution: Non-Commercial license. DOI: JMCHE/vli201 


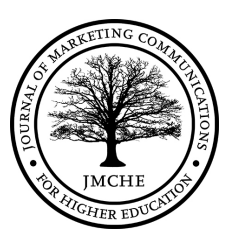

In analyzing the Brandless vision statement, it is fair to conclude that Brandless believes that brands as a whole are organizations that make better stuff inaccessible and not affordable for mainstream consumers. The Brandless vision statement also stipulates that brands are not transparent and do not adhere to community driven values, thereby making Brandless an authentic non-brand. However, Brandless fulfills all the requirements of a brand according to the definitions provided by industry branding professionals (Aaker, Kotler etc.). Brandless is seemingly capitalizing on the negative connotations associated with branded price premiums. One could argue that Brandless is pulling the veil over their customers by creating the illusion of non-brand, in essence, not being fully transparent in contrast to what the Brandless vision statement purported.

Furthermore, Brandless' affordability claim can also be in question, for instance, a 2.6 oz pouch of wild albacore tuna (Brandless) is $\$ 3$, comparatively the Starkist white albacore tuna $2.6 \mathrm{oz}$ pouch can be purchased for as little as a $\$ 1.75$.

\section{Price Comparison Between Brandless Wild Albacore Tuna ${ }^{20}$ and StarKist White Albacore Tuna ${ }^{21}$}

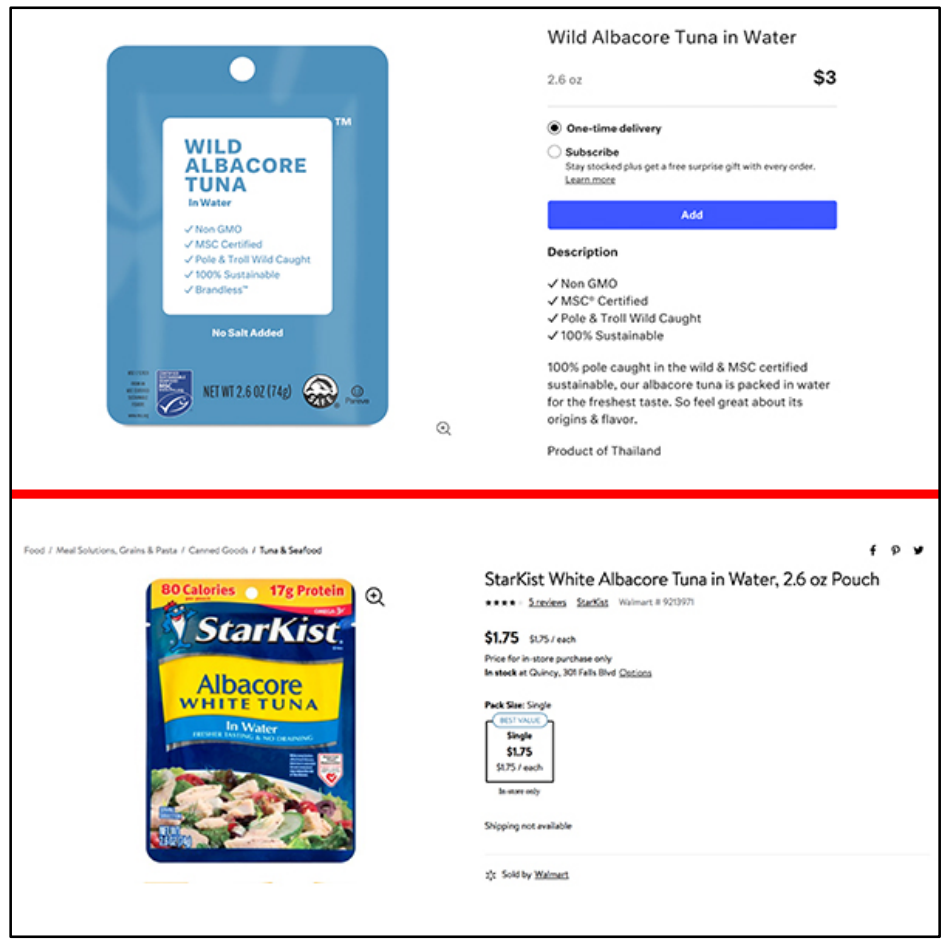

Figure 2. 2.6 oz Pouch Brandless Wild Albacore Tuna (Above), 2.6 oz Pouch StarKist White Albacore Tuna in Water (Below)

20 "Wild Albacore Tuna,” Brandless, https:/brandless.com/products/wild-albacore-tuna, (April 5, 2019).

21 "StarKist White Albacore Tuna," Walmart, https://www.walmart.com/ip/StarKist-White-Albacore-Tuna-inWater-2-6-oz-Pouch/13398013, (April 5, 2019).

(C) 2019 Patrick R. Goncalves M.S.

This open access article is licensed under a Creative Commons Attribution: Non-Commercial license. DOI: JMCHE/vli201 


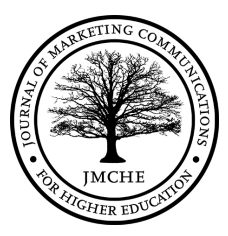

A consumer could make a case for one brand being "wild caught" in an effort to justify the price difference between Brandless and Starkist, but nonetheless that premise still runs contrary to the Brandless vision statement. Product for product, Brandless is not necessarily more affordable than branded products. In reference to symbology, the Brandless' logo is simplistic in nature, nonetheless still illustrating the same functions as any other brand-associated symbol on the market, maintaining a consistent visual theme that is strategically delivered in order to foster brand recognition.

Brandless Logo ${ }^{22}$

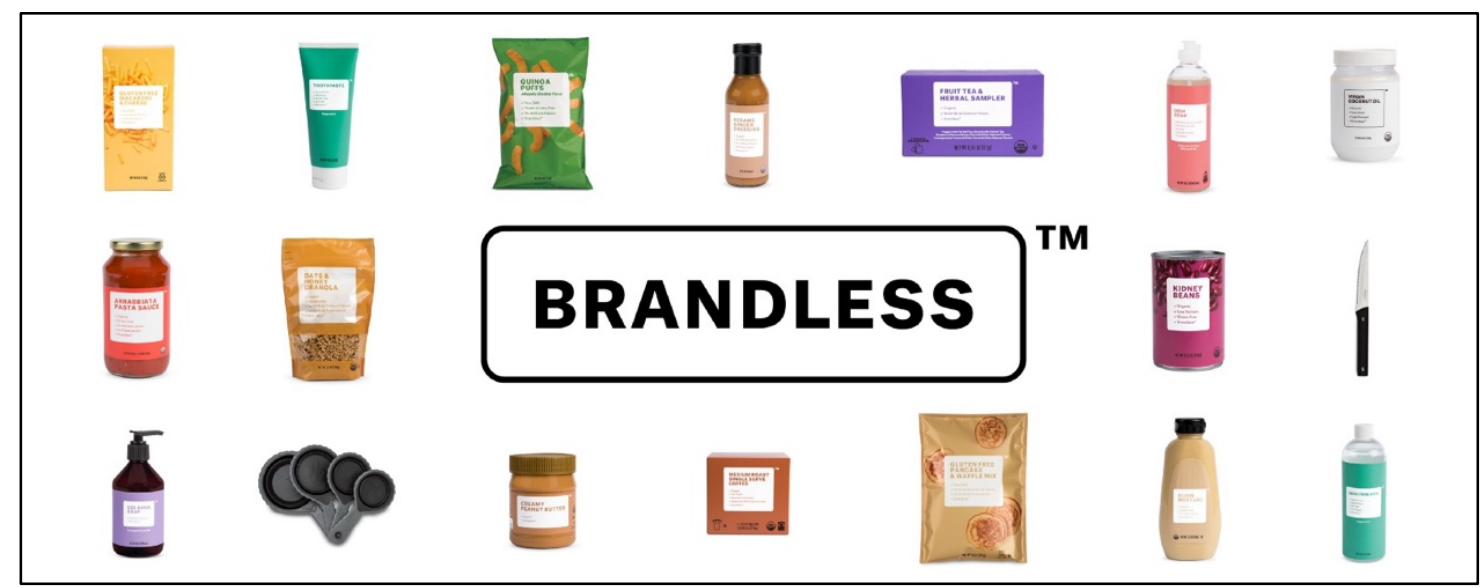

Figure 3. Brandless Logo Representation with Product Examples

In conclusion, the non-brand sentiment arguably functions as a self-expressive benefit in the brand building process; therefore, further reinforcing the approach of defining non-brand as void of information that leads to any form of brand experience.

\section{Non-Branded Product (void of information) Decision}

In order to arrive at a non-branded product (void of information), the definition of brand that specifically frameworks the brand encapsulation model, once again comes into consideration:

Any and all informational constructs that are strategically placed to provide a basis for consumeristic trust and loyalty to occur or, unintentionally not to occur, within the facilitation of any and all types of monetary transactions.

As mentioned earlier, the product qualities of still water are virtually nonexistent in terms of dynamic visual elements, water is transparent and tasteless. Ideally, the non-branded product would be represented as how it exists in nature, for example the actual Poland Spring in Maine.

22“Homepage,” Brandless, https://brandless.com, (April 5,2019).

(C) 2019 Patrick R. Goncalves M.S.

This open access article is licensed under a Creative Commons Attribution: Non-Commercial license. DOI: JMCHE/v1i201 
This would be the least impartial presentation and would be completely void of any type of branded experience while still remaining true to the product offering. In this case, the Poland Spring product offering stipulates " $100 \%$ Natural Spring Water"; while taking this fact into consideration, it is fair to conclude that water contained within a spring in Poland, Maine is in fact $100 \%$ natural because the water exists within its natural environment.

Considering that the survey is calling on respondents to report a purchase decision, it is not possible to attribute a monetary cost to a product that exists within its natural state and is free for the taking. The next question becomes, how to package a product that is completely void of any brand experience? If the product was bottled, without any type of branding information aside from the shape of the bottle, then one could conclude that the representation would be a valid non-branded representation. On the other hand, one could also pose an argument that the shape and size of the bottle plays a role in the brand experience, for instance, Glacéau Smartwater has a slender taller bottle.

\section{Glacéau Smartwater ${ }^{23}$}

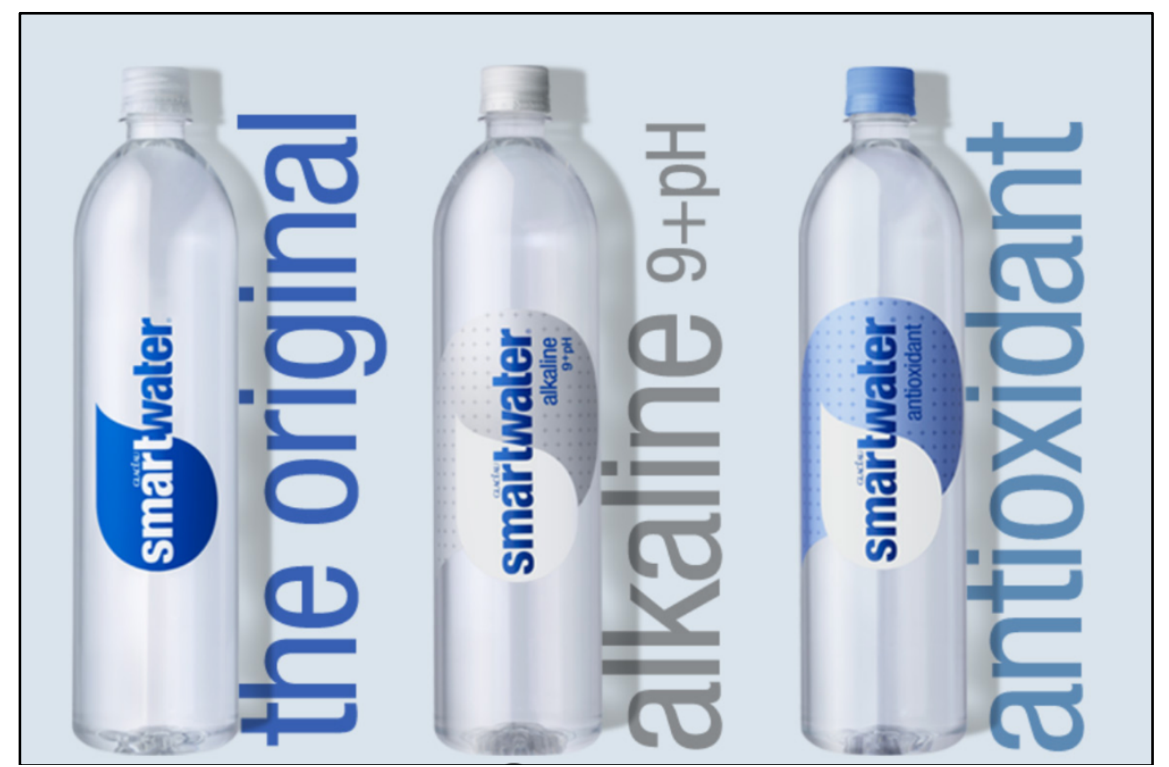

Figure 4. Presentation of Glacéau Smarwater's Unique Bottle Shape

Glacéau's decision to present this specific bottle shape is a component of the overall brand experience that the company is trying to create. As a result, a simple transparent plastic cup, much like the plastic cups purchased in bulk for festivities presents the greatest possible presentation of a non-branded experience, because the transparent plastic cups in all likelihood

23 “Homepage,” Glacéau Smartwater, https://www.drinksmartwater.com, (April 5, 2019).

(C) 2019 Patrick R. Goncalves M.S.

This open access article is licensed under a Creative Commons Attribution: Non-Commercial license. DOI: JMCHE/vli201 
will be considered a separate product serving the function of containing the purchase product (still water).

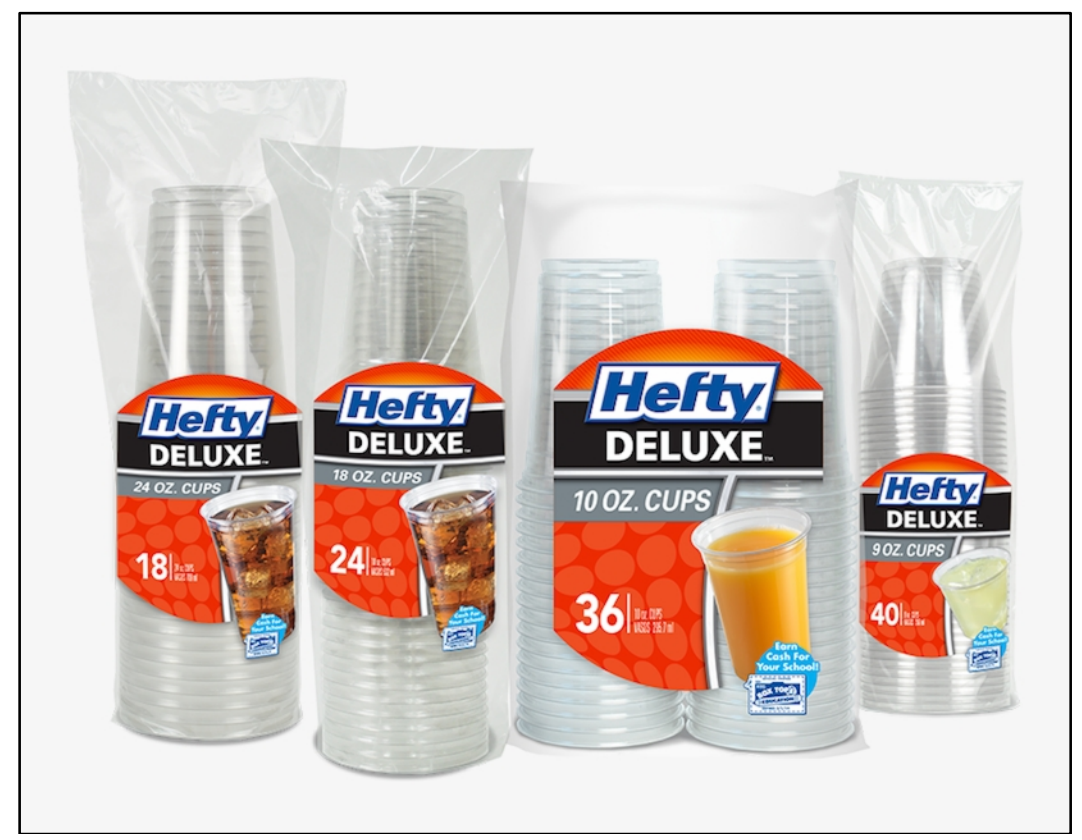

Figure 5. Example of Transparent Plastic Cups Purchased in Bulk for Festivities

The cup will not contain a lid, in order to avoid creating an experience of a packaged product which could give rise to the non-branded brand experience. Presenting the still water in an open cup also creates the closest representation of an authentic non-branded experience because the product (spring water from Poland, Maine) exists openly within its natural state. To reiterate, the still water within the cup will in fact be Poland Spring sourced water, thus both products are exactly the same in terms of product offering. Lastly there will be no information anywhere presented on the plastic cup, nor will there be any information presented to perspective respondents in regards to what the liquid actually is (100\% natural Poland Spring still water). This is to ensure that there will be no branded experience by void of information, including barebone product information. If presenting bare-bone product information alone, then one could argue the possibility of a non-branded brand experience being created as was illustrated with the examples supported in the Brandless analysis. The only valid approach to creating an authentic non-brand experience is to not present any informational constructs that can give rise to the components that comprise a brand experience.

\section{Survey Components}

The survey was presented to 50 respondents and included the following attributes: gender, age range, purchase decision, and purchase reasoning. As previously mentioned, each respondent

(C) 2019 Patrick R. Goncalves M.S.

This open access article is licensed under a Creative Commons Attribution: Non-Commercial license. DOI: JMCHE/vli201 
was presented with two product offerings, a bottled water of Poland Spring and a clear plastic cup containing Poland Spring water.

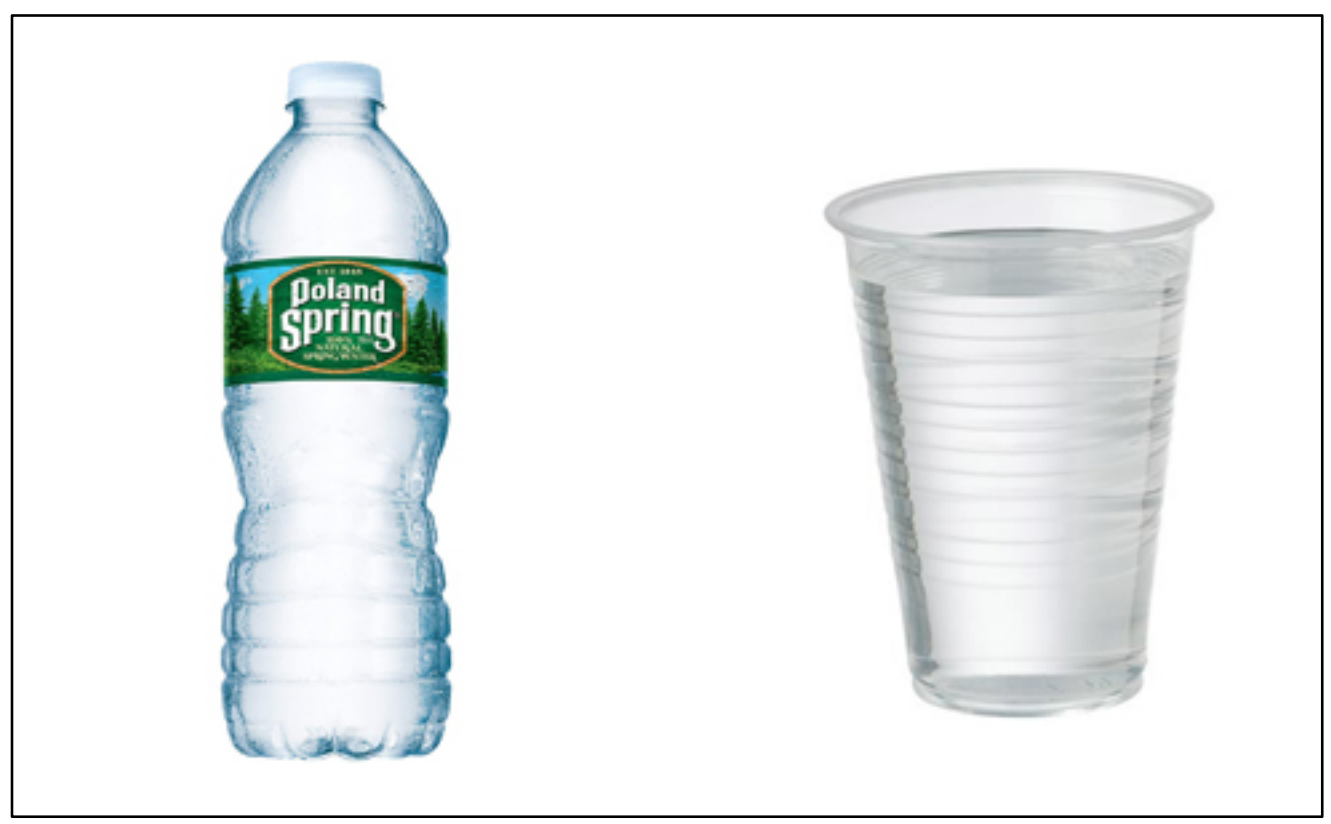

Figure 6. Poland Spring Survey Presentation | Poland Spring Still Water (Left) and Transparent Liquid in Clear Plastic Cup (Right)

Prior to a respondent's purchase decision, each respondent was provided with the following information:

The question:

If you are in the market for still water, and if you are presented with these two options: Poland Spring (followed by the Poland Spring vision statement) and liquid in a clear plastic cup; which product would you purchase, and why?

Poland Spring vision statement:

100\% Natural Spring Water and proud of it. A lot has changed since we got our start in 1845, but at least one thing remains the same: Poland Spring Brand 100\% Natural Spring Water is still sourced from our carefully selected springs in Maine. 


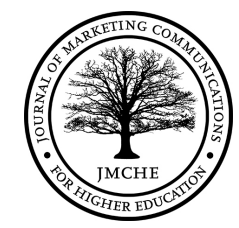

For the alternative product, the fact that Poland Spring water was in the cup was withheld from each respondent in order to create the most impartial environment for measuring brand influence on buyer's choice. No information was offered except for 4 contingencies:

1. Both products offered the same amount of liquid.

2. Both products are exactly the same price.

3. Both products are packaged with the same amount of plastic.

4. There can be no additional information offered on the product containing the liquid in the plastic cup.

5. Both products (liquids) have been exposed to exactly the same elements (given)

In an ideal setting, the sampling for respondents would be evenly distributed in regards to gender and age however, since the survey was conducted onsite within a university setting (Boston College); the Boston College population is mostly comprised of people within the 20-29 age range. As a result, $66 \%$ of the respondents were in the 20-29 age range. Please refer to Appendix A for the Poland Spring survey data.

\section{Results (Poland Spring survey)}

All respondents chose Poland Spring as the product they would purchase. To reiterate, both products were exactly the same product: $100 \%$ natural spring water from Poland, Maine. The same quantity of Poland Spring water was offered for both products, and the same amount of plastic was used to contain the spring water. Additionally, both products were exposed to the same quantity and type of elements. Considering the aforementioned premises, it is fair to conclude that there is virtually no difference between both product offerings other than one product being branded and the other, non-branded (or void of information). As a result, all respondents chose the branded product based solely on the factor pertaining to the brand experience as it relates to informational constructs that strategically provide a basis for consumeristic trust and loyalty to occur. Furthermore, when analyzing the respondent's reasons, $100 \%$ of the reasons provided contained a basis of trust and/or loyalty, which further reinforces the brand definition that frameworks the brand encapsulation model:

\section{... to provide a basis for consumeristic trust and loyalty to occur}

\section{Utilization of the Brand Encapsulation Model in Higher Education}

As a recommendation for institutions of higher education, when attributing the brand encapsulation model, stakeholders must embrace the notion that brand equals endowment. As a result, university presidents must be acclimated to making business decisions while always taking into consideration the university or college brand. University presidents should be inclined to receive training in branding to develop their perspectives in the area and broaden their understanding to give rise to a business approach that is centered on branding. While it may not

(C) 2019 Patrick R. Goncalves M.S.

This open access article is licensed under a Creative Commons Attribution: Non-Commercial license. DOI: JMCHE/v1i201 


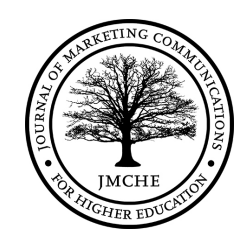

be feasible for all university/college presidents to become branding experts, there is an opportunity to create a new position that reports directly to the president, while overseeing all aspects of marketing communications and public relations across the entire university.

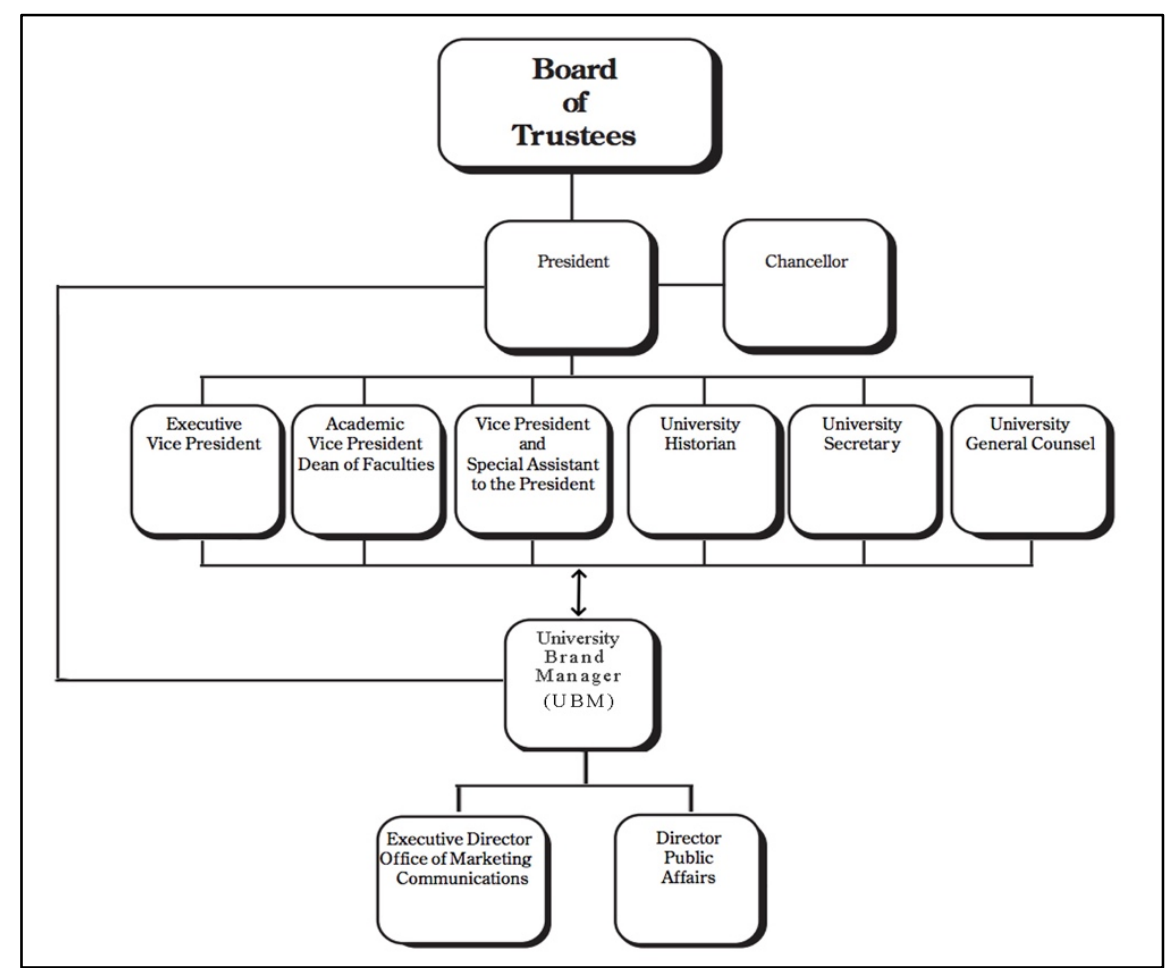

Figure 7. Example of University Admin Chart with University Brand Manager (UBM) Integration

This high-level position would be titled University Brand Manager (UBM). It is vital that the UBM and the marketing communications arm be separated from other administrative branches of the university administrative chart. The UBM needs to function as an organizational branding auditor, which is why it is essential for the role to be closely tied to the president and board of trustees. In addition, even though the UBM only oversees the marketing communications arm, the UBM will be in dialogue with executive leaders that represent various factions within the college or university, in order to garner all aspects of the university's offerings. The UBM's charge of continually conducting a university-wide brand analysis will yield branding recommendations to be approved by the president's office. Once approved, protocols and initiatives are executed in a top down fashion by the president's office. Since the encapsulation model states that brand equals endowment, the direct key performance indicator (KPI) for university wide branding initiatives will be endowment.

(C) 2019 Patrick R. Goncalves M.S.

This open access article is licensed under a Creative Commons Attribution: Non-Commercial license. DOI: JMCHE/vli201 


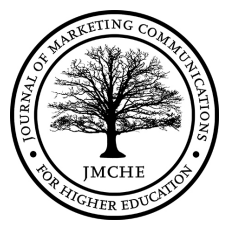

\section{Conclusion}

The Poland Spring survey confirmed the brand definition that is associated in building the framework for the brand encapsulation model. All 50 respondents provided a purchase decision based on trust and/or loyalty, thereby confirming the validity and application of the brand encapsulation model. The encapsulation model provides a straight forward methodology that offers consistency in calculating brand values. Furthermore, the Encapsulation model perspective requires that a broad organizational perspective be informed by contemporary best practices of brand strategy. 
Vol 1 Issue 2 (2019)

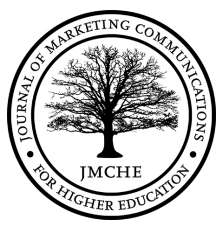

INDEX A: The Three Brand Valuation Approaches | Overview of ISO 10668-- Brand Valuation Requirements for Monetary Brand Valuation, 10 August 2011

\section{Income Approach}

The income approach values a brand as the present value of the future earnings that it is expected to generate over its remaining useful economic life. This is a commonly used approach to value businesses and other assets. Specific assumptions that require research and analysis include the brand's current cash flows, forecast growth, the risk associated with future earnings, the brand's useful economic life, and tax considerations.

The Standard lists the following income-based methods of determining the cash flow attributable to a brand.

- Price and volume premium methods: Estimate the value of a brand by reference to the price premium and/ or volume premium that it generates. In situations where a brand yields both a profit and volume premium, both methods should be applied. Consideration should also be given to cost efficiencies resulting from the brand.

- Income-split method: Values the brand as the present value of the portion of economic profit attributable to the brand. Behavioural research is used to determine the brand's contribution to economic profit.

- Multi-period excess earnings method: Values the brand as the present value of the future residual cash flow after deducting returns for all other assets required to operate the business.

- Incremental cash flow method: Identifies the cash flow generated by a brand in a business through comparison with a comparable business which does not own a brand.

- Royalty relief method: Measures the value of the brand as the present value of notional future royalty payments, assuming that the brand is not owned but licensed. This method is widely used for financial reporting and tax valuations as it is aligned with the commercial practice of licensing brands

\section{Market Approach}

Market Approach The market, or sales comparison approach, measures value in comparison with transactions, for similar brands. This approach requires a detailed evaluation of the comparability of the two brands, considering factors such as the markets in which they operate, relative brand

(C) 2019 Patrick R. Goncalves M.S.

This open access article is licensed under a Creative Commons Attribution: Non-Commercial license. DOI: JMCHE/vli201 
strength, legal protection, and the economic outlook at the times of the transactions. Account has to be taken of the fact that the price negotiated in a transaction may reflect strategic values and synergies that are not available to the present owner

\section{Cost Approach}

This approach measures the value of a brand based on the cost invested in building the brand, or its replacement or reproduction cost. It is based on the premise that a prudent investor would not pay more for a brand than the cost to replace or reproduce it. 


\title{
INDEX B: Assumptions and Analysis | Overview of ISO 10668-- Brand Valuation Requirements for Monetary Brand Valuation 10 August 2011
}

\begin{abstract}
Market and financial data
In order to gauge the current performance of the subject brand, the appraisal should carry out an analytical review of the current and forecast size of the market. Although not explicitly stated in the Standard, it is often necessary to separately evaluate all key market segments in which the brand operates, in order to take account of differences in competitive forces and market trends. Financial data referred to in the Standard includes the discount rate, tax, long term growth rates and the useful economic life of the brand. The information requirements vary depending upon the valuation approach and method that have been selected.
\end{abstract}

\section{Behavioural aspects of the brand}

The Standard uses the term 'behavioural' to describe the attitudes and behaviour of consumers and other business stakeholders. It states that "the valuation of a brand shall directly address the ways in which a brand generates value and shall consider all economic benefits that can be derived from the brand's functions in the context of the branded business". All valuation approaches require an evaluation of brand strength, the effect of the brand on demand, and the position of the brand in its key markets

\section{Legal rights attached to the brand}

Legal protection is important as it permits the brand owner to use formal legal systems to prevent third parties from exploiting the brand, thereby providing exclusivity. An assessment of the legal protection available to the brand includes an analysis of all legal rights included in the definition of the subject brand, confirmation of their ownership, and consideration of legal parameters such as distinctiveness, extent of use and notoriety. In general, the most important form of legal protection will be registered trademarks. However, common law rights and copyright might protect certain aspects of a brand. Legal rights have to be considered in all jurisdictions where the brand generates significant cash flow

(C) 2019 Patrick R. Goncalves M.S.

This open access article is licensed under a Creative Commons Attribution: Non-Commercial license.

DOI: JMCHE/v1i201 
Vol 1 Issue 2 (2019)

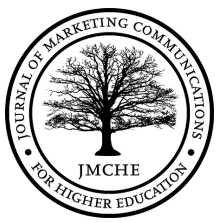

\section{INDEX C: Applications of Brand Valuation | Overview of ISO 10668--Brand Valuation Requirements for Monetary Brand Valuation 10 August 2011}

\section{Budget setting}

As with other assets, it is hard to know how much to invest in a brand without understanding its current worth, and whether value will be added, or eroded, by alternative levels of investment. Even in organizations where the brand is acknowledged as a key asset, the marketing budget can be vulnerable in the absence of a robust business case.

\section{Resource allocation}

Which region, channel, product, or customer segment should get the next dollar of marketing budget? There is no better way of answering the question than gauging the brand value implications within each segment.

\section{Scenario valuations}

Scenario valuations allow marketers to forecast the impact of different strategies on brand value - thereby stripping out the usual subjective arguments that accompany strategy determination. At the outset it is often unclear which strategy will yield the best result. Once market trends, consumer research and financial information have been integrated into a valuation model the choice usually becomes clear.

\section{Brand architecture}

Brand architecture dilemmas are a common reason for organizations to undertake a brand valuation. The underlying issue can be:

- a swollen portfolio of brands resulting from mergers and acquisitions;

- the intention to extend a strong brand into new product categories;

- concern that the existing brand lacks relevance in new product segments.

Views on the benefits of new brands, sub-brands, umbrella brands and brand termination are often strongly held - and polarizing. The use of brand valuation models avoids subjective arguments by integrating market research into a framework that places a value on each option.

(C) 2019 Patrick R. Goncalves M.S.

This open access article is licensed under a Creative Commons Attribution: Non-Commercial license. DOI: JMCHE/vli201 
Vol 1 Issue 2 (2019)

\section{Reputation risk management}

The fine print of branding says that value can go down as well as up. Risk management procedures should identify events that could erode the value of brands and corporate reputation. It is then possible to develop responses that mitigate the risk.

\section{Marketing dashboards}

A brand value framework highlights the measures that matter, and prevents dashboards being a random collection of measures. Value-based dashboards enable marketers to focus on the best opportunities, allocate budgets to activities that have the greatest impact, measure the results, and articulate the return on brand investment. 
Vol 1 Issue 2 (2019)

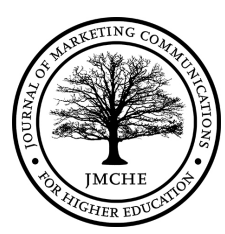

\section{APPENDIX A: Poland Spring Survey Data}

\begin{tabular}{|c|c|c|c|c|}
\hline $\begin{array}{l}\text { Respondent } \\
\text { \# }\end{array}$ & Gender & Age & $\begin{array}{l}\text { Purchase } \\
\text { Choice }\end{array}$ & Reasons \\
\hline \# 1 & female & $30 \mathrm{~s}$ & $\begin{array}{l}\text { Poland } \\
\text { Spring }\end{array}$ & $\begin{array}{l}\text { "Just by looking at it, it makes you feel more comforted going } \\
\text { with the Poland Spring brand, it's safe and pure, the other one } \\
\text { looks like you could've just gotten it from a sink, which actually } \\
\text { might be better for you, but mentally we don't think that way." }\end{array}$ \\
\hline \#2 & male & $60 \mathrm{~s}$ & $\begin{array}{l}\text { Poland } \\
\text { Spring }\end{array}$ & $\begin{array}{l}\text { "I don't like plastic cups, I would never drink out of one if I could } \\
\text { avoid it. The Poland Spring picture looks like a natural pure } \\
\text { place. The water must be pure." }\end{array}$ \\
\hline \# 3 & female & $20 \mathrm{~s}$ & $\begin{array}{l}\text { Poland } \\
\text { Spring }\end{array}$ & $\begin{array}{l}\text { "The other product is just a cup of water...I think? I pick the } \\
\text { Poland Spring." }\end{array}$ \\
\hline \# 4 & female & $20 \mathrm{~s}$ & $\begin{array}{l}\text { Poland } \\
\text { Spring }\end{array}$ & $\begin{array}{l}\text { "It's a brand, colorful; Poland Spring is the brand I drink at home. } \\
\text { I know it and trust it." }\end{array}$ \\
\hline \# 5 & female & $20 \mathrm{~s}$ & $\begin{array}{l}\text { Poland } \\
\text { Spring }\end{array}$ & $\begin{array}{l}\text { "Poland Spring is the brand I drink at home, and so I know the } \\
\text { brand--wouldn't drink out of something that was open." }\end{array}$ \\
\hline \# 6 & female & $20 \mathrm{~s}$ & $\begin{array}{l}\text { Poland } \\
\text { Spring }\end{array}$ & $\begin{array}{l}\text { "I don't know what is in the other cup, I like having my water } \\
\text { packaged. I pick } \\
\text { Poland Spring." }\end{array}$ \\
\hline \# 7 & female & $20 \mathrm{~s}$ & $\begin{array}{l}\text { Poland } \\
\text { Spring }\end{array}$ & "I am familiar with the Poland Spring brand and I trust it." \\
\hline \# 8 & female & $20 \mathrm{~s}$ & $\begin{array}{l}\text { Poland } \\
\text { Spring }\end{array}$ & $\begin{array}{l}\text { "I don't know what is in the cup, I know and use Poland Spring } \\
\text { water, I trust it." }\end{array}$ \\
\hline \# 9 & female & $20 \mathrm{~s}$ & $\begin{array}{l}\text { Poland } \\
\text { Spring }\end{array}$ & "I know the Poland Spring brand and I trust it." \\
\hline \# 10 & female & $20 \mathrm{~s}$ & $\begin{array}{l}\text { Poland } \\
\text { Spring }\end{array}$ & $\begin{array}{l}\text { "Poland Spring is packaged with a cap, I don't trust anything } \\
\text { without a cap." }\end{array}$ \\
\hline \# 11 & female & $20 \mathrm{~s}$ & $\begin{array}{l}\text { Poland } \\
\text { Spring }\end{array}$ & "I love Poland Spring water, and I know the brand." \\
\hline \# 12 & female & $20 \mathrm{~s}$ & $\begin{array}{l}\text { Poland } \\
\text { Spring }\end{array}$ & $\begin{array}{l}\text { "I know Poland Spring is the best tasting water, crisp and } \\
\text { refreshing." }\end{array}$ \\
\hline \# 13 & female & $20 \mathrm{~s}$ & $\begin{array}{l}\text { Poland } \\
\text { Spring }\end{array}$ & "I know the Poland Spring brand, and I trust it." \\
\hline \# 14 & female & $20 \mathrm{~s}$ & $\begin{array}{l}\text { Poland } \\
\text { Spring }\end{array}$ & $\begin{array}{l}\text { "I would purchase Poland Spring because I feel it's cleaner and } \\
\text { safer." }\end{array}$ \\
\hline \# 15 & female & $20 \mathrm{~s}$ & $\begin{array}{l}\text { Poland } \\
\text { Spring }\end{array}$ & "I'm familiar with Poland Spring, it's bottled and so I trust it." \\
\hline \# 16 & female & $20 \mathrm{~s}$ & Poland & "I would purchase Poland Spring because it's bottled." \\
\hline
\end{tabular}

(C) 2019 Patrick R. Goncalves M.S.

This open access article is licensed under a Creative Commons Attribution: Non-Commercial license.

DOI: JMCHE/vli201 
Vol 1 Issue 2 (2019)

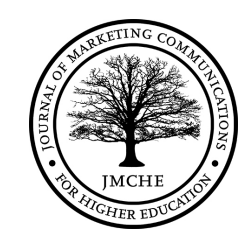

\begin{tabular}{|c|c|c|c|c|}
\hline & & & Spring & \\
\hline \# 17 & female & $20 \mathrm{~s}$ & $\begin{array}{l}\text { Poland } \\
\text { Spring }\end{array}$ & "I would buy Poland Spring because I trust it more." \\
\hline \# 18 & male & $20 \mathrm{~s}$ & $\begin{array}{l}\text { Poland } \\
\text { Spring }\end{array}$ & "Known the Poland Spring brand, I trust it." \\
\hline \# 19 & male & $20 \mathrm{~s}$ & $\begin{array}{l}\text { Poland } \\
\text { Spring }\end{array}$ & $\begin{array}{l}\text { "Poland Springs has an encouraging message and I like the } \\
\text { packaging." }\end{array}$ \\
\hline \# 20 & male & $20 \mathrm{~s}$ & $\begin{array}{l}\text { Poland } \\
\text { Spring }\end{array}$ & "I like the fact that Poland Spring is packaged." \\
\hline \# 21 & male & $20 \mathrm{~s}$ & $\begin{array}{l}\text { Poland } \\
\text { Spring }\end{array}$ & $\begin{array}{l}\text { "The other product doesn't look like it's purified water, that's why } \\
\text { I'm going with Poland Spring." }\end{array}$ \\
\hline \# 22 & male & $20 \mathrm{~s}$ & $\begin{array}{l}\text { Poland } \\
\text { Spring }\end{array}$ & "I like the fact that Poland Spring is $100 \%$ spring water." \\
\hline \# 23 & male & $20 \mathrm{~s}$ & $\begin{array}{l}\text { Poland } \\
\text { Spring }\end{array}$ & "Poland Spring is an established brand name." \\
\hline \# 24 & male & $20 \mathrm{~s}$ & $\begin{array}{l}\text { Poland } \\
\text { Spring }\end{array}$ & "I trust Poland Spring because it's packaged." \\
\hline \# 25 & male & $20 \mathrm{~s}$ & $\begin{array}{l}\text { Poland } \\
\text { Spring }\end{array}$ & "The Poland Spring bottle offers more information." \\
\hline \# 26 & male & $20 \mathrm{~s}$ & $\begin{array}{l}\text { Poland } \\
\text { Spring }\end{array}$ & "I know Poland Spring, I trust what I'm buying." \\
\hline \# 27 & male & $20 \mathrm{~s}$ & $\begin{array}{l}\text { Poland } \\
\text { Spring }\end{array}$ & "I prefer water that is bottled, so I'm going with Poland Spring." \\
\hline \# 28 & male & $20 \mathrm{~s}$ & $\begin{array}{l}\text { Poland } \\
\text { Spring }\end{array}$ & "I trust Poland Spring, I like the way the bottle looks too." \\
\hline \# 29 & male & $20 \mathrm{~s}$ & $\begin{array}{l}\text { Poland } \\
\text { Spring }\end{array}$ & "I trust the offering, and I prefer bottled water." \\
\hline \# 30 & male & $20 \mathrm{~s}$ & $\begin{array}{l}\text { Poland } \\
\text { Spring }\end{array}$ & "I would buy Poland Spring, more trustworthy." \\
\hline \# 31 & male & $20 \mathrm{~s}$ & $\begin{array}{l}\text { Poland } \\
\text { Spring }\end{array}$ & "I trust Poland Spring." \\
\hline \# 32 & male & $20 s$ & $\begin{array}{l}\text { Poland } \\
\text { Spring }\end{array}$ & "Poland Spring is a trusted brand, you know what you're getting." \\
\hline \# 33 & male & $20 \mathrm{~s}$ & $\begin{array}{l}\text { Poland } \\
\text { Spring }\end{array}$ & "I trust Poland Spring, I know the brand." \\
\hline \# 34 & male & $20 \mathrm{~s}$ & $\begin{array}{l}\text { Poland } \\
\text { Spring }\end{array}$ & $\begin{array}{l}\text { "I know the Poland Spring brand, the brand familiarity gives me a } \\
\text { reason to trust it." }\end{array}$ \\
\hline \# 35 & male & $20 s$ & Poland & "I trust it, I know the brand." \\
\hline
\end{tabular}

(C) 2019 Patrick R. Goncalves M.S.

This open access article is licensed under a Creative Commons Attribution: Non-Commercial license.

DOI: JMCHE/vli201 
Vol 1 Issue 2 (2019)

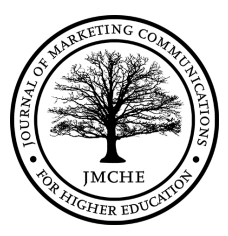

\begin{tabular}{|c|c|c|c|c|}
\hline & & & Spring & \\
\hline \# 36 & female & $30 \mathrm{~s}$ & $\begin{array}{l}\text { Poland } \\
\text { Spring }\end{array}$ & $\begin{array}{l}\text { "I don't want to buy a product that I know nothing about. I know } \\
\text { and trust Poland Spring, I'm going with that one." }\end{array}$ \\
\hline \# 37 & female & $30 \mathrm{~s}$ & $\begin{array}{l}\text { Poland } \\
\text { Spring }\end{array}$ & $\begin{array}{l}\text { "The liquid in the cup could be anything, I don't trust it. I pick } \\
\text { Poland Spring." }\end{array}$ \\
\hline \# 38 & Male & $30 \mathrm{~s}$ & $\begin{array}{l}\text { Poland } \\
\text { Spring }\end{array}$ & $\begin{array}{l}\text { "I have no idea what the other product is...is it water? How can I } \\
\text { trust it? There is no chance I would consider purchasing it. I pick } \\
\text { Poland Spring." }\end{array}$ \\
\hline \# 39 & male & $40 \mathrm{~s}$ & $\begin{array}{l}\text { Poland } \\
\text { Spring }\end{array}$ & "I'm going with Poland Spring, because I trust it." \\
\hline \# 40 & male & $40 \mathrm{~s}$ & $\begin{array}{l}\text { Poland } \\
\text { Spring }\end{array}$ & "I trust Poland Spring." \\
\hline$\# 41$ & female & $50 \mathrm{~s}$ & $\begin{array}{l}\text { Poland } \\
\text { Spring }\end{array}$ & "I'm a Poland Spring consumer; I know and trust the brand." \\
\hline$\# 42$ & male & $50 \mathrm{~s}$ & $\begin{array}{l}\text { Poland } \\
\text { Spring }\end{array}$ & $\begin{array}{l}\text { "The Poland Spring bottle has a lid. I don't trust something } \\
\text { without a lid." }\end{array}$ \\
\hline \# 43 & female & $60 \mathrm{~s}$ & $\begin{array}{l}\text { Poland } \\
\text { Spring }\end{array}$ & $\begin{array}{l}\text { "People trust the Poland Spring brand. Natural water comes from } \\
\text { the mountain just like in the picture. I pick Poland Spring because } \\
\text { that water is branded." }\end{array}$ \\
\hline$\# 44$ & female & $60 \mathrm{~s}$ & $\begin{array}{l}\text { Poland } \\
\text { Spring }\end{array}$ & "I know the Poland Spring brand and trust it." \\
\hline$\# 45$ & male & $30 \mathrm{~s}$ & $\begin{array}{l}\text { Poland } \\
\text { Spring }\end{array}$ & $\begin{array}{l}\text { "I don't want to pay for something that I don't know what I'm } \\
\text { paying for. I know what I'm paying for when I buy Poland } \\
\text { Spring." }\end{array}$ \\
\hline$\# 46$ & female & $50 \mathrm{~s}$ & $\begin{array}{l}\text { Poland } \\
\text { Spring }\end{array}$ & "I buy Poland Spring, so I trust the product." \\
\hline \# 47 & female & $50 \mathrm{~s}$ & $\begin{array}{l}\text { Poland } \\
\text { Spring }\end{array}$ & $\begin{array}{l}\text { "I'm familiar with the product (Poland Spring). I don't know } \\
\text { anything about the other product. There is no information, how } \\
\text { do I know what I'm buying?" }\end{array}$ \\
\hline \# 48 & female & $40 \mathrm{~s}$ & $\begin{array}{l}\text { Poland } \\
\text { Spring }\end{array}$ & $\begin{array}{l}\text { "I have already bought Poland Spring in the past, so I choose } \\
\text { Poland Spring." }\end{array}$ \\
\hline \# 49 & female & $30 \mathrm{~s}$ & $\begin{array}{l}\text { Poland } \\
\text { Spring }\end{array}$ & "I trust Poland Spring." \\
\hline \# 50 & male & $30 \mathrm{~s}$ & $\begin{array}{l}\text { Poland } \\
\text { Spring }\end{array}$ & "I recognize the Poland Spring brand-I pick Poland Spring." \\
\hline
\end{tabular}

(C) 2019 Patrick R. Goncalves M.S.

This open access article is licensed under a Creative Commons Attribution: Non-Commercial license.

DOI: JMCHE/vli201 
Vol 1 Issue 2 (2019)

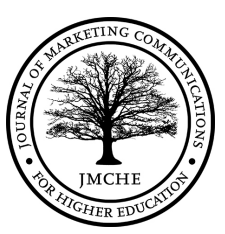

\section{References}

Aaker, David A. Building Strong Brands. New York, NY: Free Press, 1996.

Aaker, David. "Brand Equity vs. Brand Value: What's the Difference?" Prophet. May 17, 2018. Accessed March 20, 2019. https://www.prophet.com/2016/09/brand-equity-vs-brand-value/.

Aaker, David. "Brands as Assets: The Idea That Transformed Marketing." Prophet. May 15, 2018. Accessed March 23, 2019. https://www.prophet.com/2014/07/200-brands-as-assets-theidea-that-transformed-marketing/.

Aaker, David. "David Aaker." David Aaker. Accessed March 5, 2019. https://www.prophet.com/author/david-aaker/.

"About." Brandless. Accessed April 05, 2019. https://brandless.com/about.

"Better Stuff. Fewer Dollars. It's That Simple." Brandless. Accessed April 05, 2019. https://brandless.com/.

Brand Z Top 100 Most Valuable Global Brands. Report. Brand Z. Millward Brown, 2018. 1-147.

December 13, 2009. "Define: Brand." Seth's Blog. May 30, 2018. Accessed March 05, 2019. https://seths.blog/2009/12/define-brand/).

Folger, Jean. "What Is an Asset?" Investopedia. March 28, 2019. Accessed March 23, 2019. https://www.investopedia.com/ask/answers/12/what-is-an-asset.asp.

The publication was updated on 3/28/2019

France, Mark BonchekCara. "Build Your Brand as a Relationship." Harvard Business Review. May 09, 2016. Accessed March 20, 2019. https://hbr.org/2016/05/build-your-brand-as-arelationship.

"HOME." Poland Spring® Brand 100\% Natural Spring Water. Accessed March 23, 2019. https://www.polandspring.com/.

"Homepage." Official Smartwater® Website. Accessed April 05, 2019. https://www.drinksmartwater.com/.

(C) 2019 Patrick R. Goncalves M.S.

This open access article is licensed under a Creative Commons Attribution: Non-Commercial license. DOI: JMCHE/vli201 
Vol 1 Issue 2 (2019)

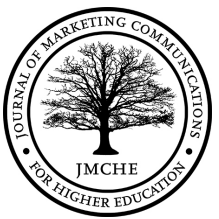

How Accurate Are the Brand Value Rankings? - Findings of a Comparative Analysis of Brand Values from Different Sources. Report. MARKABLES. Schwyz, Switzerland: MARKABLES, 2015. 1-14.

"How Strong Is Your Company's Brand? An ISO Standard Can Help Tell You." ISO. October 20, 2010. Accessed March 20, 2019. https://www.iso.org/news/2010/10/Ref1364.html.

Kotler, Philip, and Gary Armstrong. Principles of Marketing. Upper Saddle River: Pearson, 2018.

"OUR SPRINGS." Poland Spring ${ }^{\circledR}$ Brand 100\% Natural Spring Water. Accessed March 23, 2019. https://www.polandspring.com/our-springs.

Overview of ISO 10668: Brand Valuation Requirements for Monetary Brand Valuation 10 August 2011. Report. Australian Marketing Institute \& Brand Finance. Sydney, NSW: Australian Marketing Institute \& Brand Finance. 1-16.

Ritson, Mark. "Mark Ritson: What Is the Point of Brand Valuations If Those Doing the Valuing Are so off Target? - Marketing Week." Marketing Week. August 01, 2017. Accessed March 20, 2019. https://www.marketingweek.com/2015/04/22/what-is-the-point-of-brand-valuations-ifthose-doing-the-valuing-are-so-off-target/.

Ritson, Mark. "Brand Valuation: Brilliant or Bullshit? - Marketing Week." Marketing Week. August 08, 2017. Accessed March 23, 2019. https://www.marketingweek.com/2015/12/08/brand-valuation-brilliant-or-bullshit/.

"StarKist White Albacore Tuna in Water, 2.6 Oz Pouch ..." Accessed April 5, 2019. https://www.walmart.com/ip/StarKist-White-Albacore-Tuna-in-Water-2-6-oz-Pouch/13398013.

Tmr. "TMR." Key Facts About the Global Bottled Water Market: Read More Below. July 04, 2018. Accessed March 23, 2019.

https://www.transparencymarketresearch.com/pressrelease/bottled-water-market.htm.

"Wild Albacore Tuna in Water - 2.6 Oz." Brandless. Accessed April 05, 2019. https://brandless.com/products/wild-albacore-tuna.

(C) 2019 Patrick R. Goncalves M.S.

This open access article is licensed under a Creative Commons Attribution: Non-Commercial license. DOI: JMCHE/vli201 